\title{
HUBUNGAN POWER OTOT TUNGKAI DAN PANJANG TUNGKAI TERHADAP KECEPATAN LARI 100 METER
}

\author{
Hendi $^{1}$, Andika Triansyah ${ }^{2}$, Muhamad Fachrurrozi Bafadal ${ }^{3}$ \\ ${ }^{1}$ Mahasiswa Program Studi Pendidikan Jasmani FKIP Untan Pontianak. \\ ${ }^{2,3}$ Dosen Program Studi Pendidikan Jasmani FKIP Untan Pontianak \\ Email: ${ }^{1}$ f1102161033@student.untan.ac.id, ${ }^{2}$ andika.triansyah@fkip.untan.ac.id, \\ ${ }^{3}$ mfachrurrozibafadal@fkip.untan.ac.id
}

\begin{abstract}
This study aims to determine the relationship between leg muscle power and leg length to the 100 meter running speed of the extracurricular members of SMAN 1 Teluk Batang. The method used is correlational with quantitative descriptive research. The data source of this research is students who take extracurricular activities with running speed of 100 meters and the data is to do a series of tests and measurements then the assessment is taken from the best score. The results showed that there was a relationship between leg muscle power and the results of running speed 100 meters $r$ count $>r$ table $(-0.7>0.514)$, there was a relationship between leg length and the result of running speed $100 \mathrm{r}$ count $>\mathrm{r}$ table $(-0.82>$ $0.514)$, there was a power relationship. leg muscles and leg length to running speed 100 meters rcount> rtable (4.2>0.15). So, leg muscle power and leg length to 100 meter running speed have a significant relationship to the results of 100 meters running speed.
\end{abstract}

Keywords: Power of leg muscles, leg length, running speed of 100 meters.

\begin{abstract}
Abstrak: Penelitian ini bertujuan untuk mengetahui hubungan antara kekuatan otot tungkai dan panjang tungkai terhadap kecepatan lari 100 meter pada peserta ekstrakurikuler SMAN 1 Teluk Batang. Metode yang digunakan adalah korelasional dengan penelitian deskriptif kuantitatif. Sumber data dalam penelitian ini adalah siswa yang mengikuti kegiatan ekstrakurikuler dengan kecepatan lari 100 meter dan datanya dilakukan serangkaian tes dan pengukuran kemudian diambil penilaiannya dari skor terbaik. Hasil penelitian menunjukkan bahwa ada hubungan antara kekuatan otot tungkai dengan hasil kecepatan lari 100 meter $\mathrm{r}$ hitung > $r$ tabel $(-0,7>0,514)$, ada hubungan antara panjang tungkai dengan hasil kecepatan lari $100 \mathrm{r}$ hitung $>\mathrm{r}$ tabel $(-0,82>0,514)$, ada hubungan kekuasaan. Otot tungkai dan panjang tungkai untuk kecepatan lari 100 meter rhitung> rtabel (4.2> 0.15). Jadi, kekuatan otot tungkai dan panjang tungkai terhadap kecepatan lari 100 meter memiliki hubungan yang signifikan dengan hasil kecepatan lari 100 meter.
\end{abstract}

Kata kunci: Kekuatan otot tungkai, panjang tungkai, kecepatan lari 100 meter.

$\mathrm{S}$ ekolah merupakan lembaga pendidikan yang menampung peserta didik dan dibina agar mereka memiliki kecerdasan dan kemampuan. Dengan demikian siswa diharapkan dapat mencapai prestasi belajar yang maksimal sehingga tercapainya tujuan pendidikan. Salah satu mata pembelajaran dalam kurikulum pendidikan di sekolah adalah pendidikan jasmani. 


\section{Jurnal Pendidikan Jasmani Kesehatan dan Rekreasi (Penjaskesrek) \\ Volume 8, Nomor 1, Januari 2021}

Pendidikan jasmani bertujuan meningkatan pertumuhan fisik peserta didik dengan melalui gerak-gerak dasar yang sudah dimiliki sejak lahir oleh setiap manusia itu sendiri. sehingga siswa pendidikan jasmani dapat meningkatkan aktivitas gerak yang mengacu pada fungsi tubuh secara spesifik dalam kaitanya dengan sistem saraf itu sendiri, dalam pendidikan jasmani ini dipacu untuk meningkatkan kebugaran pada anak dengan cara melakukan gerak-gerak yang sudah teratur dan secara sistematis. Pendidikan jasmani mewujudkan tujuan pendidikan melalui aktifitas jasmani atau fisik, (Triansyah, 2020:2). Materi dalam pendidikan jasmani yang termuat dalam perangkat pembelajaran salah satunya adalah aktivitas gerak atletik.

Atletik dapat menjadi salah satu kegiatan yang digemari dalam penjasorkes di SMA sesuai dengan ciri perkembangannya, peserta didik di sekolah pada dasarnya sudah terampil melakukan unsur gerakan kegiatan atletik. Dalam bidang non-akademik, sekolah memfasilitasi pengembangan bakat siswa melalui pengadaan kegiatan ekstrakurikuler baik yang bersifat olahragamaupun non-olahraga.

Adapun kegiatan ekstrakurikuler yang ada di SMAN 1 Teluk Batang Kabupaten Kayong Utara sebagai berikut, yaitu: Pramuka, Paskibra, Silat, KIR (kelompok ilmiah remaja), Bola Voli, ROHIS (rohani islam), Seni Tari dan Sepakbola, atletik, tenis meja, PMR (palang merah remaja). Hal ini sangat penting dilakukan untuk mengatasi masalah para siswa terutama bagi siswa yang mengalami kesulitan dalam akademis.

Berdasarkan hasil observasi dan wawancara dengan guru penjaskes khususnya SMAN 1 Teluk Batang Kayong Utara bahwa kemampuan siswa dalam melakukan lari 100 meter masih belum diketahui kecepatan lari peserta ekstrakulikuler yang memiliki kemampuan yang berbeda-beda, adapun beberapa peserta ekstrakulikuler yang memiliki power yang baik namun prestasi lari sisiwa tidak begitu bagus, hal ini dapat dilihat dari hasil tes yang dilakukan oleh guru penjas, dari hasil tes tersebut diketahui siswa yang menempuh waktu 13,5 detik sebesar $40 \%$ sedangkan $60 \%$ siswa melakukan lari sprint dengan waktu lebih dari 13,5 detik.

Dari hasil pengamatan di lapangan pada waktu tes, dapat dilihat bahwa masih banyak ditemukan siswa yang tidak maksimal dalam melaksanakan sprint 100 meter, sehingga peserta ekstrakulikuler sering terlambat menuju garis finish. Hal tersebut disebabkan kurang maksimal dalam melaksanakan sprint 100 meter, belum bisa mengatur jangkauan langkah kaki dalam melakukan lari 100 meter, dan tolakakan kaki pada saat lari yang kurang maksimal.Salah satu penyebab yang lainnya adalah faktor 


\section{Jurnal Pendidikan Jasmani Kesehatan dan Rekreasi (Penjaskesrek) \\ Volume 8, Nomor 1, Januari 2021}

kemampuan fisik siswa yang mempengaruhi pada saat melakukan lari sprint seperti panjang tungkai karena hal tersebut dapat mempengaruhi jangkauan langkh pada saat berlari.

Dari latar belakang yang telah dipaparkan di atas, peneliti tertarik ingin mengetahui hubungan power otot tungkai dan panjang tungkai apakah ada hubungan terhadap hasil kecepatan lari 100 meter pada peserta ekstrakulikuler SMAN 1 Teluk Batang Kayong Utara yang optimal”.

"Power adalah kapasitas para siswa untuk mengotraksikan secara maksimum, atau power sebagai suatu ledakan yang menghasilkan kecepatan dalam waktu yang singkat, desakan ini dilakukan dengan kekuatan otot dan kecepatan", (Afandi, 2019 :32)

"Otot tungkai atas terdapat otot muskulus abduktor yang berfungsi menyelenggarakan gerakan abdukasi dari femur. Muskulus ekstensor (quadriseps femoris). Otot fleksor femoris", (mariani 2017: 75). "sebagai penopang tegaknya tubuh, otot tungkai memberikan manfaat yang sangat besar didalam ayunan tungkai”, Paturohman (2017: 126). "Otot tungkai bawah terdiri tulang kering, anterior, ekstensor, tendo achilles, falangus longus, tibialis posterior", (Tobrani, 2016: 17).

“Tungkai adalah anggota tubuh bagian bawah atau disebut juga dengan extrimitas inferior, yang mana terdiri dari pinggul, paha, betis dan kaki”, (Arfan, 2011: 87). "kecepatan adalah suatu kemampuan tubuh untuk melakukan sebuah gerakan dengan cepat mudah dan dengan tempo waktu yang sesingkat-singkatny”, (Afandi 2019: 31).

\section{MOTODE PENELITIAN}

Dalam penelitian ini penulis menggunakan metode penelitian kuantitatif. Bentuk penelitian yang sesuai dengan penelitian ini adalah dengan studi korelasi, maka bentuk penelitian ini adalah studi korelasi karena bermaksud mengungkapkan hubungan power otot tungkai, dan panjang tungkai terhadap kecepatan lari 100 meter peserta ekstrakulikuler SMAN 1 Teluk Batang Kayong utara.

Dalam rancangan penelitian ini peneliti menetapkan populasi yakni, peserta didik yang mengukuti ekstrakulikuler SMAN 1 teluk Batang Kayong Utara yang berjumlah 15 orang.

Peneliti mengambil sampel sebanyak 15 org dikarenakan disekolah tersebut memiliki lebih dari satu jenis ekstrakulikuler sehingga siswa memilih ekstrakulikuler lain selain dari ekstrakulikuler sprint, selian itu ekstrakulikuler lari tidak di wajibkan untuk ikut serta.

Teknik pengambilan sampel dalam penelitian ini menggunakan teknik sampling 
jenuh. pada penelitian ini yaitu dengan metode tes dan Pengukuran. Tes dilakaukan 3 kali, yang pertama tes power otot tungkai, panjang tungkai dan yang terakhir tes lari 100 meter.

Penelitian ini adalah penelitian korelasi menggunakan dua variabel independen (X) dan satu variabel dependen (Y) dengan mencari hubungan $\mathrm{X}_{1}$ terdapat $\mathrm{Y}, \mathrm{X}_{2}$ terdapat $\mathrm{Y}$, dan $\mathrm{X}_{1} \mathrm{X}_{2}$ terdapat $\mathrm{Y}$. Desain penelitian tersebut divisualisasikan sebagai berikut:

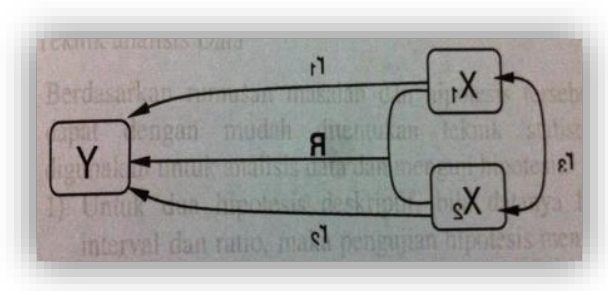

Gambar 1 skema hubungan variabel Sumber: Sugiyono, (2018: 69)

\section{TEKNIK PENGUMPULAN DATA DAN INSTRUMEN}

Teknik pengumpulan data dalam penelitian ini yaitu dengan metode tes dan Pengukuran. Tes dilakaukan 3 kali, yang pertama tes power otot tungkai, panjang tungkai dan yang terakhir tes lari 100 meter. Dari hasil tes, maka dapat diperoleh data dari hasil penelitian.

a. Tes power otot tungkai menggunakan Vartical jump (Modified Sargent Jump).

Pelaksanaan dan alat yang diperlukan

1) Pita pegukur atau permukaan

2) Tembok diberi ukuran.
Siswa diperintahkan berdiri di samping tembok di mana pita pengukur itu berada. Masukan salah satu tangannya yang paling dekat dengan tembok kedalam air agar jari jarinya basah. Kemudian siswa coba tegak, tangan yang sudah dibasahi angkat setinggi mungkinke atas dan sentuhkan /letakan ari jari itu ke tembok, sampai terlihat dengan jelas bekasnya.

Dalam hal ini, perlu diperhatikan bahwa sama sekali siswa tidak diperbolehkan membengkokkan tubuhnya atau mengangkat tumitnya (jinjit). Bekas jari - jari diukur dan dicatat. Berikut siswa mulai dengan percobaannya dengan tampak jelas jari-jari. Siswa melakukan percobaan ini sampai tiga kali. Selisih antara tanda dalam sikip permulaan dan hasil loncatan tertingg nilah diukur.

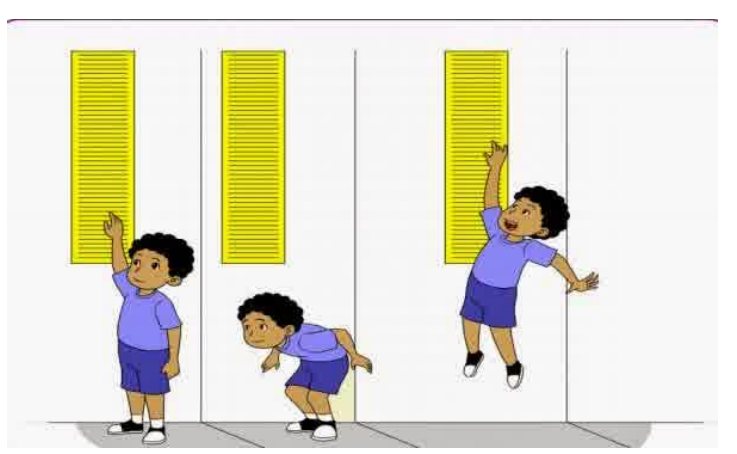

Gambar 2. Vartical jump (Modified Sargent

Jump)

Sumber : Widiastuti, (2015 : 109).

b. Tes Panjang Tungkai

Pengukuran panjang tungkai

dilakukan dengan cara : 


\section{Jurnal Pendidikan Jasmani Kesehatan dan Rekreasi (Penjaskesrek)}

Volume 8, Nomor 1, Januari 2021

1) Siswa berdiri dengan posisi anatomi pada lantai yang datar tanpa mengenakan alas kaki

2) Panjnag tungkai diukur dari tulang belakang terbawah atau trochanter sampai ke lantai.

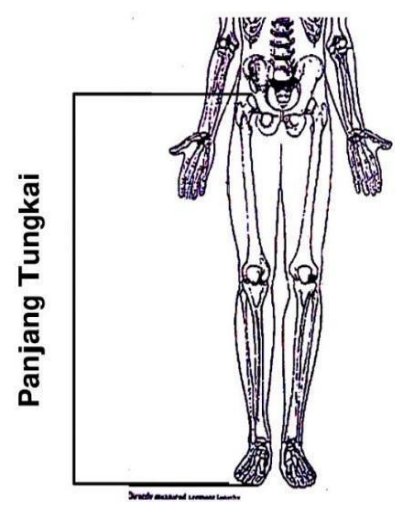

Gambar 3.3 Panjang Tungkai

Sumber : Permana (2020: 136).

c. Tes kecepatan lari 100 meter

Untuk mengukur hasil

kecepatan lari 100 digunakan

tes lari 100 meter.

\section{TEKNIK ANALISIS DATA}

Penelitian ini adalah penelitian korelasi menggunakan dua variabel independen (X) dan satu variabel dependen (Y) dengan mencari hubungan $\mathrm{X}_{1}$ terdapat $\mathrm{Y}, \mathrm{X}_{2}$ terdapat $\mathrm{Y}$, dan $\mathrm{X}_{1} \mathrm{X}_{2}$ terdapat $\mathrm{Y}$. Penghitungan dalam penelitian ini menggunakan stastik deskriptif dan dilakukan uji persyaratan, uji hipotesis meliputi uji korelasi ganda, uji regresi sederhana dan uji regresi ganda, sedangkan uji persyaratan meliputi uji normalitas data, uji homogenitas dan uji linieritas regresi, analisis data dalam penelitian ini peneliti menggunakan komputerisasi.

$$
\tau=\frac{\sum \mathrm{A}-\sum \mathrm{B}}{\frac{\mathrm{N}(\mathrm{N}-1)}{2}} \text { Rumus } 9.46
$$

Sumber: Sugiyono, (2015: 390).

Di mana

$\tau=$ koefikasi korelasi kendala tua yang bersama $(-1<0<1)$

$\mathrm{H}=$ jumlah rangking atas

$\mathrm{L}=$ jumlah rangking bawah

$\mathrm{N}=$ jumlah angota sampel

\section{Hasil Penelitian}

Penelitian ini bertujuan untuk mengetahui hubungan power otot tungkai dan panjang tungkai terhadap kecepatan lari 100 meter pada peserta ekstrakulikuler SMAN Teluk Batang Kayong Utara.

\section{Uji Normalitas}

Tujuan uji normalitas adalah untuk mengetahui apakah data yang diperoleh dari tiaptiap variabel yang dianalisis sebenarnya mengikuti pola sebaran normal atau tidak. Kaidah yang digunakan untuk mengetahui normal tidaknya suatu sebaran adalah $p>0,05$ sedangkan dinyatakan normal, dan jika $p<0,05$ seberan dinyatakn tidak normal.

Tabel 1 Hasil Uji Normalitas.

Variabel $\quad p \quad$ Sig Keterangan




\begin{tabular}{|c|c|c|c|}
\hline Power & & \multirow{4}{*}{0,05} & \\
\hline Otot & 1,98 & & Normal \\
\hline Tungkai & & & \\
\hline $\begin{array}{l}\text { Panjang } \\
\text { Tungkai }\end{array}$ & 1,98 & & Normal \\
\hline Kecepatan & \multirow[b]{2}{*}{0,1425} & & \multirow[b]{2}{*}{ Normal } \\
\hline $\begin{array}{c}\text { Lari } 100 \\
\text { Meter }\end{array}$ & & 257 & \\
\hline
\end{tabular}

Dari tabel 1 di atas, menunjukkan bahwa nilai signifikansi (p) adalah lebih besar dari 0,05, sedangkan untuk lari lebih semakin kecil maka semakin bagus hasilnya jadi hasil lari dikatakan normal karena (p) lebih kecil dari r tabel 0, 257, jadi, data adalah berdistribusi normal.

\section{Uji Linearitas}

Pengujian linieritas hubungan dilakukan melalui uji regresi linier berganda. Hubungan antara variabel $\mathrm{X}$ dengan $\mathrm{Y}$ dinyatakan linier apabila nilai $\mathrm{p}>0,05$.

\section{Tabel 2.Uji Linearitas}

$\begin{array}{cccc}\begin{array}{c}\text { Hubungan } \\ \text { Fungsional }\end{array} & p & \text { Sig } & \text { Keterangan } \\ \frac{\mathrm{X} 1 . \mathrm{Y}}{\mathrm{X} 2 . \mathrm{Y}} & 13,45 & 0,05 & \frac{\text { Linier }}{\text { Linier }}\end{array}$

Dari tabel 2 di atas, terlihat bahwa nilai hubungan variabel bebas dengan variabel terikatnya dinyatakan linear.

\section{Uji Korelasi Ganda}

Untuk memperjelas hubungan antara variabel bebas dengan variabel terikat maka dilakukan analisis regresi berganda.

1. Hubungan antara power otot tungkai dengan kecepatan lari 100 meter.

\section{Tabel 3}

\begin{tabular}{cccc} 
Korelasi & rhitung & $\mathrm{r}_{\text {tabel }}$ & Keterangan \\
\hline $\mathrm{X}_{1} . \mathrm{Y}$ & 0,7 & 0,514 & Signifikan
\end{tabular}

Berdasarkan hasil analisis tersebut di atas diperoleh koefisien korelasi antara panjang tungkai dengan kecepatan lari 100 meter sebesar 0,7 bernilai positif, artinya semakin baik panjang tungkai, maka semakin baik nilai kecepatan lari 100 meter.

2. Hubungan antara panjang tungkai dengan kecepatan lari 100 meter.

\section{Tabel 4}

\begin{tabular}{cccc} 
Korelasi & rhitung & $\mathrm{r}$ tabel & Keterangan \\
\hline $\mathrm{X} 2 . \mathrm{Y}$ & 0,82 & 0,514 & Signifikan
\end{tabular}

Berdasarkan hasil analisis tersebut di atas diperoleh koefisien korelasi antara panjang tungkai dengan kecepatan lari 100 meter bernilai positif, artinya semakin baik panjang tungkai, maka semakin baik nilai kecepatan lari 100 meter.

3. Hubungan antara power otot tungkai dan panjang tungkai terhadap kecepatan lari 100 meter. 


\section{Jurnal Pendidikan Jasmani Kesehatan dan Rekreasi (Penjaskesrek)}

Volume 8, Nomor 1, Januari 2021

Tabel 5

\begin{tabular}{cccc} 
Korelasi & rhitung & $\mathrm{r}$ tabel & Keterangan \\
\hline $\mathrm{X}_{1}, \mathrm{X}_{2}$ & 4,2 & 0,514 & Signifikan \\
dan Y & & &
\end{tabular}

\section{B Pembahasan}

Penelitian ini bertujuan untuk mengetahui hubungan power otot tungkai dan panjang tungkai terhadap kecepatan lari 100 meter pada peserta ekstrakulikuler SMAN Teluk Batang Kayong Utara. Hasil penelitian dijelaskan sebagai berikut:

1. Hubungan power otot tungkai terhadap kecepatan lari 100 meter.

Berdasarkan hasil analisis menunjukkan bahwa terdapat hubungan yang signifikan antara power otot tungkai dengan kecepatan lari 100 meter pada peserta ekstrakulikuler SMAN 1 Teluk Batang Kayong Utara. Adanya hubungan power otot tungkai terhadap kecepatan lari 100 meter, ternyata daya ledak otot tungkai dapat menimbulkan kekuatan dan kecepatan yang baik dengan demikian kecepatan berlari akan baik pula.

2. Hubungan panjang tungkai terhadap kecepatan lari 100 meter

Berdasarkan hasil analisis menunjukkan bahwa terdapat hubungan yang signifikan antara panjang tungkai dengan kecepatan lari 100 meter pada peserta ekstrakulikuler SMAN 1 Teluk Batang Kabupaten Kayong Utara. Besarnya sumbangan panjang tungkai terhadap kecepatan lari 100 meter.
3. Hubungan power otot tungkai dan panjang tungkai terhadap kecepatan lari 100 meter.

Berdasarkan hasil analisis menunjukkan bahwa terdapat hubungan yang signifikan antara power otot tungkai dan panjang tungkai terhadap kecepatan lari 100 meter pada peserta ekstrakulikuler SMAN Teluk Batang.

Besarnya sumbangan power otot tungkai dan panjang tungkai terhadap kecepatan lari 100 meter. Ternyata powet otot tungkai dan panjang tungkai pada tubuh peserta ekstrakulikuler dalam penelitian ini dapat menghasilkan kecepatan lari 100 meter yang lebih baik. Unsur fisik ini salah satu yang perlu dilatih dan diperhatikan oleh pelatih, guru, dan dosen dalam melatih kecepatan lari 100 meter seorang siswa atau atlet.

\section{A Kesimpulan}

Berdasarkan dari analisis penelitian yang telah di paparkan sebelumnya, dapat disimpulkan hasil dalam penelitian ini. Berikut kesimpulan dalam penelitian ini:

1. Ada hubungan yang signifikan antara power otot tungkai dengan kecepatan lari 100 meter $r$ hitung $>r$ tabel $(-0,7>0,514)$, pada peserta ekstrakulikuler SMAN 1 Teluk Batang Kayong Utara.

2. Ada hubungan yang signifikan antara panjang tungkai dengan kecepatan lari 
100 meter rtabel $(-0,82>0,514)$, pada peserta ekstrakulikuler SMAN 1 Teluk Batang Katong Utara.

3. Ada hubungan yang signifikan antara power otot tungkai dan panjang tungkai terhadap kecepatan lari 100 meter rhitung $>$ rtabel $(4,2>0,15)$. Jadi, Power power otot tungkai dan panjang tungkai terhadap kecepatan lari 100 meter memiliki hubungan yang signifikansi terhadap hasil kecepatan lari 100 meter.

\section{B Saran}

Berdasarkan kesimpulan penelitian di atas, ada beberapa saran yang dapat disampaikan yaitu:

1. Dalam upaya peningkatan kemampuan berlari sprint 100 meter, hendaknya para peserta ekstrakulikuler serta guru harus memperhatikan komponen power otot tungkai panjang tungkai, karena kedua komponen ini sangat berperan dalam peningkatan kemampuan lari sprint 100 meter.

2. Bagi para guru ekstrakulikuler didalam melatih para atlit hendaknya diimbangi dengan peningkatan kondisi fisik berupa powor otot tungkai dan panjang tungkai sehingga latihan yang dilakukan dapat berhasil.

3. Penelitian ini dapat dilanjutkan oleh peneliti lain dalam permasalahan yang lebih luas dengan jumlah sampel yang lebih besar, sehingga dapat memberikan sumbangan pemikiran kepada mahasiswa dalam meningkatkan kemampuan lari sprint 100 meter.

4. Penelitian ini dapat menjadikan masukan bagi peneliti sendiri dan memperkaya khasanah ilmu pengetahuan tentang penelitian dan dalam mengadakan penelitian berikutnya dapat menjadi lebih baik.

\section{Daftar Pustaka}

Afandi. 2019. Buku Ajar Pendidikan Dan

Perkembangan Motorik. Ponogoro

Uwis Inspirasi Indonesia.

Arfan. 2011. Hubungan Sprint Dan Daya

Ledak Otot Tungkai Terhadap Hasil

Lompat Jauh Gaya Jongkok.F

Iswandi, E Purnomo - Jurnal

Pendidikan dan Pembelajaran

Volune 2 Nomor 4. 2013 -

jurnal.untan.ac.id

Mariani 2017. Kurniawan. 2016. Pembinaan

Cabang Olahraga Atletik Pplpd

Kabupaten Nganjuk.A Idris - Jurnal

Kesehatan Olahraga, Volume 4

Nomor 4. Tahun2016 -

jurnalmahasiswa.unesa.ac.id

Paturahman 2017. Satya. 2011. Pengaruh

Metode Abc Running Terhadap Hasil

Belajar Teknik Lari Jarak Pendek 60

Meter.Mizar Agari, Victor Gaberius

Simanjuntak, Mimi Haetami Jurnal 
Jurnal Pendidikan Jasmani Kesehatan dan Rekreasi (Penjaskesrek)

Volume 8, Nomor 1, Januari 2021

Pendidikan Dan jurnal.untan.ac.id

Volum 8 Nomor 6 Juni 2019

Permana 2020. Psikologi Olahraga. PT Edu

Tama

Sugiono 2018. Metode Penelitian

Pendidikan Pendekatan Kuantitatif

Kuanlitatif, dan $R \& D$. Alfabeta

Bandung.

- 2015. Metode Penelitian Pendidikan

Pendekatan Kuantitatif Kuanlitatif,

dan R\&D. Alfabeta Bandung.

Tobarini 2016. Pembinaan Cabang Olahraga

Atletik Pplpd Kabupaten Nganjuk.A

Idris-Jurnal Kesehatan Olahraga,

volume 4 nomor 4 tahun2016 -

jurnalmahasiswa.unesa.ac.id

Triansyah, A. Atmaja, N. M. K. Abdurrochim, M. Bafadal, M. F. 2020.

Peningkatan karakter kepedulian dan kerjasama dalam pembelajaran mata kuliah atletik Jurnal Pendidikan Jasmani Indonesia, Vol.16,(2), 145-

155. Diunduh di journal.uny.ac.id 